\title{
RANCANG BANGUN SISTEM INFORMASI PENDAYAGUNAAN ASET DINAS PERKEBUNAN PROVINSI RIAU
}

\author{
Surya Andika'), Siti Ramadhani ${ }^{2)}$ \\ ${ }^{1}$ Fakultas Sains Dan Teknologi, Universitas Islam Negeri Sultan Syarif Kasim, Jl.Merpati Sakti Gg.Bayu 1 \\ email: 11850114647@students.uin-suska.ac.id \\ ${ }^{2}$ Fakultas Sains Dan Teknologi, Universitas Islam Negeri Sultan Syarif Kasim, Jl. HR. Soebrantas Panam \\ Km 15, Panam, Pekanbaru \\ email: siti.ramadhani@uin-suska.ac.id
}

\begin{abstract}
Abstrak
Dinas Perkebunan Provinsi Riau adalah suatu instansi yang bertugas melaksanakan urusan pemerintahan dan perkebunan. Provinsi Riau memiliki dua jenis aset, yaitu aset tetap dan aset tidak tetap, untuk itu diperlukan nya sebuah sistem informasi untuk pendayagunaan aset. Sementara sistem yang digunakan saat ini untuk pengajuan dan pencatatan laporan aset masih dilakukan secara manual menggunakan formulir pengajuan kemudian diserahkan kebagian perlengkapan aset dan dalam pencatatan aset masih menggunakan pembukuan laporan informasi aset. Dari masalah tersebut juga terdapat keluhan dari beberapa pegawai dari bidang lain, dengan proses yang cukup ribet karena harus bolak balik ke ruangan perlengkapan dalam pengajuan permintaan barang. Untuk mempermudah pengelolaan nya, dibuatlah sebuah Sistem Informasi Pendayagunaan Aset yang di harapkan dapat membantu kinerja pegawai Dinas Perkebunan Provinsi Riau. Metodologi yang digunakan dalam pembuatan sistem adalah metode Agile dengan aktifitas yang berpusat pada pengembangan model menggunakan Unified Model Language(UML). Berdasarkan hasil pengujian blackbox dan User Acceptance Test(UAT) didapatkan bahwa Sistem Informasi yang telah dirancang dapat memudahkan pekerjaan pegawai, dan administrator bidang perlengkapan/aset dalam melakukan pengajuan aset, konfirmasi pengajuan, cetak laporan aset dan pengelolaan data aset.
\end{abstract}

Keywords: Laravel, Pendayagunaan aset, MySQL, PHP, Sistem Informasi

\begin{abstract}
The Riau Province Plantation Service is an agency in charge of carrying out government and plantation affairs. Riau Province has two types of assets, namely fixed assets and non-fixed assets. For that, we need an information system for asset utilization. While the system currently used for filing and recording asset reports is still done manually using a submission form then submitted to the asset equipment division. In recording assets, it still uses asset information report bookkeeping. There were also complaints from several employees from other fields from this problem, with a fairly complicated process because they had to go back and forth to the equipment room in submitting requests for goods. To facilitate its management, an Asset Utilization Information System was created, which is expected to help the performance of the Riau Province Plantation Office employees. The methodology used in making the system is the Agile method, with activities centered on model development using the Unified Model Language (UML). Based on the BlackBox testing and User Acceptance Test (UAT) results, the Information System designed can facilitate the work of employees and administrators in the field of equipment/assets in submitting assets, confirming submissions, printing assets reports and managing asset data.
\end{abstract}

Keywords: Laravel, Asset Utilization, MySQL, PHP, Information Systems 


\section{PENDAHULUAN}

Dinas Perkebunan Provinsi Riau yang berada di J1.Cut Nyak Dien No.6 Pekanbaru merupakan suatu instansi yang bertanggung jawab atas penyelenggaraan urusan pemerintahan yang menjadi milik kekuasaan daerah, dan membantu tugas di bidang prasarana, sarana dan prasarana, pembinaan dan pembibitan tanaman, pembinaan dan pembinaan tanaman, pengolahan, pemasaran dan pengembangan usaha, serta perlindungan dan data sesuai dengan ketentuan peraturan perundangundangan.

Instansi ini terdiri dari beberapa Sub Bagian, Bidang, dan Unit Pelayanan Teknis (UPT), yaitu Sub Bagian Perencanaan Program, Sub Bagian Keuangan dan Pengelolaan Barang Milik Daerah, Sub Bagian Umum dan Kepegawaian, Bidang Produksi Perkebunan, Bidang Pengembangan Usaha dan Penyuluhan, Bidang Sarana dan Prasarana, Bidang Pengolahan dan Pemasaran Hasil Perkebunan, UPT Produksi Benih Perkebunan, UPT Pengawasan dan Sertifikasi Benih.

Di bagian perlengkapan, dimana penulis melaksanakan kerja praktik, masih ada kekurangan dalam pengelolaan aset. Yaitu proses permintaan barang pada setiap bidang maupun UPT ke bagian perlengkapan dan pembuatan laporan stok opname yang masih menggunakan excel dan input secara manual. Untuk proses permintaan barang ini masih menggunakan cara lama/tulis tangan dengan mengisi form permintaan barang, setiap pegawai dari salah satu bidang atau UPT yang ingin melakukan permintaan barang harus mengisi form untuk permohonan / kebutuhan barang yang disediakan oleh bagian perlengkapan, kemudian pegawai tersebut menyerahkan formulir / surat tersebut. Lalu bagian perlengkapan akan memeriksa apakah stok barang masih tersedia dan sesuai, jika sesuai, tim akan memprosesnya, dan jika tidak, akan mengembalikan formulir. Tentunya bagian peralatan yang bertanggung jawab atas pengelolaan aset harus mencatat semua data terkait proyek aset, yang merupakan informasi penting yang diberikan oleh Dinas Perkebunan Riau.

Dari permasalahan yang ada, disini penulis mendapatkan ide untuk membangun atau merancang suatu sistem yang diharapkan bisa mempermudah pekerjaan yang sebelumnya menggunakan cara lama kini beralih menggunakan cara yang baru, yaitu pengajuan permintaan yang dilakukan lewat sistem berbasis web.[1]-[9] Kemudian bisa memaksimalkan kinerja bagian perlengkapan, lebih teratur, efektif dan efisien.

Dalam membangun suatu sistem informasi diperlukan batasan masalah sesuai dengan kemampuan penulis dan agar tidak melenceng dari permasalahan yang ada. Batasan masalah dari sistem yang akan dibuat adalah

1. Pengelolaan data aset,

2. Pengajuan permintaan barang

3. Konfirmasi permintaan

4. Laporan stok opname aset.

\section{LANDASAN TEORI}

Sistem merupakan kumpulan elemen yang saling berhubungan satu sama lain yang membentuk satu kesatuan dalam usaha mencapai suatu tujuan. Di dalam perusahaan, yang di maksud elemen dari sistem adalah departemen internal, seperti persedian barang mentah, produksi, promosi, penjualan, keuangan, personalia dll, sehingga membentuk satu kesatuan[10].

Pada umumnya sistem informasi merupakan sebuah sistem yang ada pada 
sebuah organisasi dimana di dalamnya terdapat kombinasi yang terdiri dari kumpulan orang, fasilitas, teknologi bahkan cara kerja atau metode sehingga menciptakan alur sebuah komunikasi serta pemprosesan beragam tipe kejadian internal maupun eksternal yang dapat dijadikan sebagai sebuah dasar dalam penentuan keputusan berdasarkan informasi yang terdapat pada sistem tersebut[11].

Dalam suatu informasi terdapat komponen-komponen yang harus diperhatikan seperti:

1. Perangkat keras (hardware)

2. Perangkat lunak (software)

3. Prosedur

4. Orang

5. Basis data (database)

6. Jaringan Komputer dan Komunikasi Data

Model Pembangunan Sistem pada penelitian ini menggunakan Agile Development. Agile development sendiri merupakan model pengembangan perangkat lunak dalam jangka pendek. Kemudian, membutuhkan adaptasi yang cepat dalam mengatasi setiap perubahan. Nilai terpenting dari Agile development ini adalah memungkinkan sebuah tim dalam mengambil keputusan dengan cepat, kualitas dan prediksi yang baik, serta memiliki potensi yang baik dalam menangani setiap perubahan.

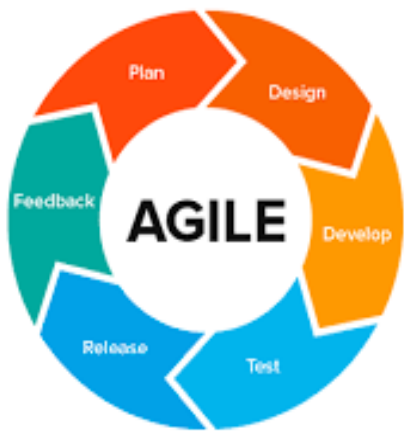

Gambar 1 Metode Agile

Pengembangan perangkat lunak Agile memiliki beberapa tahapan dalam mengembangkan suatu proyek/perangkat lunak. Tahapan-tahapan tersebut adalah sebagai berikut:

1. Perencanaan

2. Implementasi

3. Tes perangkat lunak

4. Dokumentasi

5. Deployment

6. Pemeliharaan

Alat analisis sistem digunakan untuk simbol umum dalam desain sistem teknis.Program analisis akan digunakan sebagai panduan selama konstruksi dan implementasi sistem pengembangan. Berikut adalah perangkat analisa sistem yang digunakan:

1. Use Case Diagram

2. Use case description

3. Sequence diagram

4. Class diagram

5. PHP

6. MySQL

7. Laravel Framework

\section{METODE PENELITIAN}

Adapun metode penelitian dalam pelaksanaan kerja prakek di Dinas Perkebunan Provinsi Riau adalah sebagai berikut: 


\section{a. Perencanaan}

Pada tahap ini penulis melakukan perencanaan dengan mengumpilkan datadata yang berkaitan dengan sistem yang akan dibangun. Adapun data yang dikumpulkan oleh penulis adalah sebagai berikut:

1. Studi Pustaka

Penelitian literatur dilakukan dengan membaca buku dan jurnal yang berkaitan dengan pengembangan sistem dan pembuatan laporan.

2. Wawancara (interview)

Wawancara dilakukan dengan Bapak Darwis sebagai pegawai yang bekerja pada Bidang Perlengkapan, diskusi ini dilakukan untuk memahami alur proses bisnis yang ada pada instansi dan pegawai memberikan masukan untuk rancangan sistem yang akan dibangun.

3. Observasi

Observasi adalah melihat dan mengamati secara langsung proses pengelolaan, penyerahan dan pencatatan aset.

\section{b. Tahap Implementasi}

Pada tahap ini, penulis mengimplementasikan sistem aplikasi analisis yang diperoleh sebagai kodingan, menggunakan bahasa pemrograman PHP dan database MySQL untuk membangun sistem. Pada tahap pengujian dilakukan uji kompatibilitas terlebih dahulu, apakah sistem sesuai dengan analisis dan perlu diterapkan pada instansi.

c. Tes perangkat lunak dan Deployment

Pada tahap pengujian dilakukan uji kompatibilitas terlebih dahulu, apakah sistem sesuai dengan analisis dan perlu diterapkan pada instansi. Dan tahap deployment dilakukan untuk menjamin kualitas dari sistem yang dibangun. d. Dokumentasi dan Pemeliharaan

Setelah tahap tes perangkat lunak dan deployment, langkah selanjutnya adalah dokumentasi dan pemeliharaan. Karena tidak ada sistem yang $100 \%$ bebas dari bug, maka tahap pemeliharaan sangat penting dilakukan secara berkala.

\section{HASIL DAN PEMBAHASAN}

Setelah melakukan analisis untuk mengetahui permasalahan di instansi Dinas Perkebunan pada ruang lingkup aset, kemudian didapatkan lah hasil dari analisis tersebut yaitu:

1. Sering terjadi kekeliruan akibat permintaan barang yang masih menggunakan formulir.

2. Sulit untuk mengetahui jumlah stok barang yang masih tersedia.

3. Pembuatan laporan stok opname yang masih harus di ketik ulang dan kurang efektif.

Oleh karena itu, sistem ini diharapkan dapat membantu bidang perlengkapan dalam mengelola data aset, sehingga dapat menghemat waktu dan mengurangi permintaan barang yang tidak teratur.

\section{a. Analisa Sistem Baru}

Berdasarkan permasalahan pada sistem yang lama, penulis merekomendasikan suatu analisis. Kemudian akan dirancang dan dibangun sistem informasi manajemen aset, yang nantinya akan digunakan sebagai pengelola data untuk penyerahan aset dan pencatatan laporan aset[12]-[15]. Sistem ini melibatkan dua pengguna, yaitu: administrator dan pegawai dari berbagai bidang: 


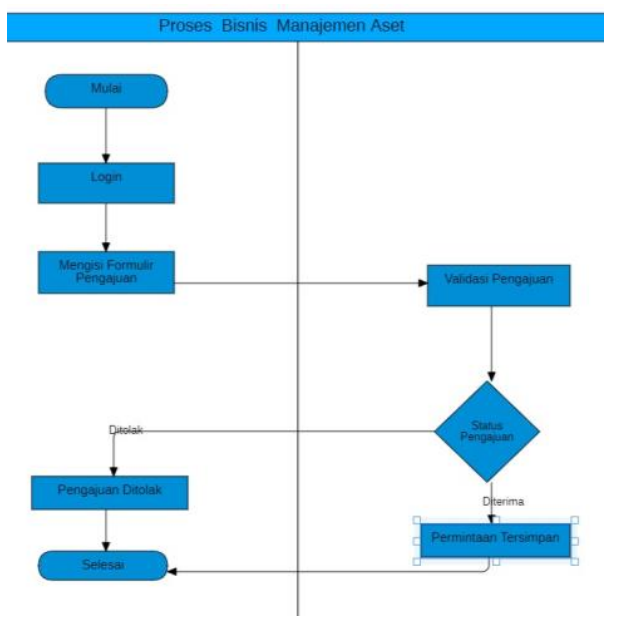

Gambar 1 Flowchart sistem baru

\section{b. Use Case Diagram}

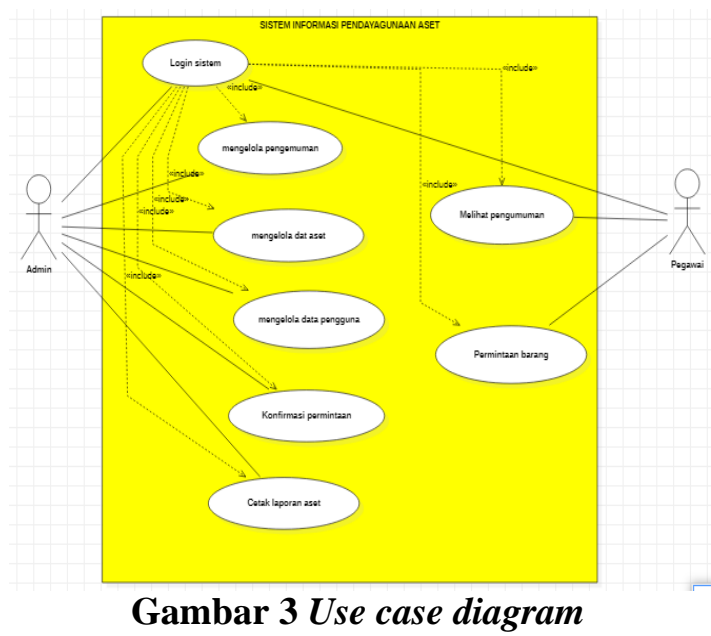

Use case diagram digunakan untuk menggambarkan interaksi antara partisipan dan sistem yang dibuat. Use case diagram juga berguna untuk memahami fungsifungsi apa saja yang ada pada sistem dan siapa yang berhak atau mengakses fungsifungsi tersebut[16].

\section{c. Class Diagram}

Class Diagram adalah salah satu jenis diagram yang paling berguna di UML, hal ini karena dapat dengan jelas memetakan struktur sistem tertentu dengan memodelkan kelas, atribut, operasi serta hubungan antar objek. Berikut adalah gambaran class diagram pada sistem:

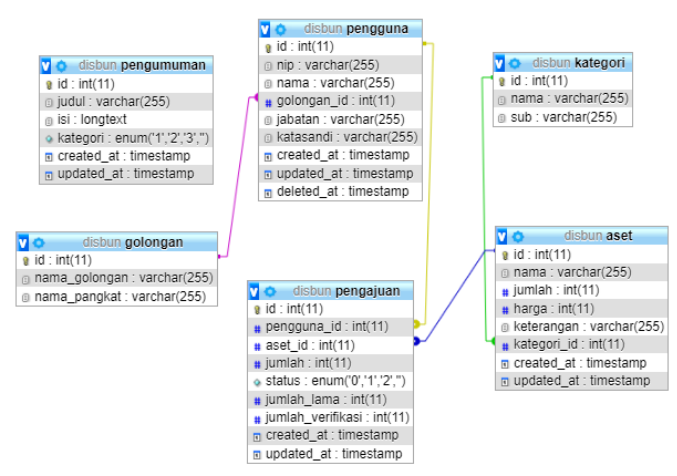

Gambar 4 Class diagram

d. Implementasi

- Implementasi tampilan login

Sebelum masuk ke halaman utama user diarahkan ke halaman login, dan mengisi form login.

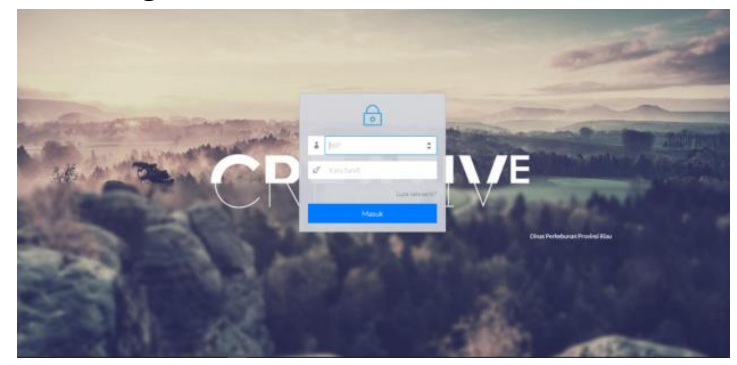

Gambar 5 Tampilan Login

- Implementasi beranda/halaman utama Setelah melakukan login user diarahkan ke halaman beranda, dan bisa mengakses halaman tersebut.

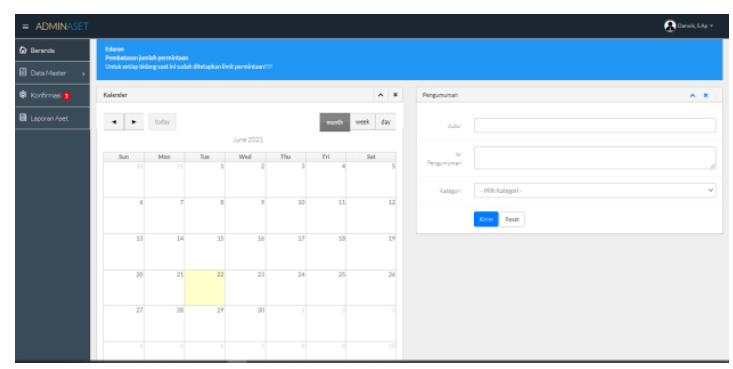

Gambar 6. Tampilan Beranda/Halaman Utama(Admin) 
- Implementasi Tampilan Data Aset Ini adalah tampilan dalam pengelolaan asset, yang hanya bisa di akses oleh user admin.

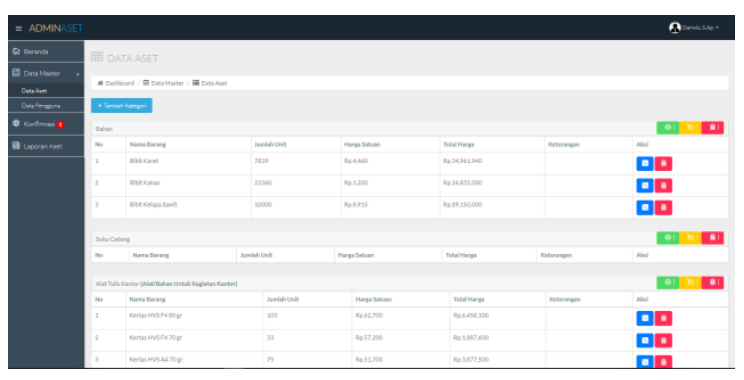

Gambar 7 Tampilan Data Aset

- Implementasi Tampilan Data

Pengguna

Di tampilan ini adalah proses pengelolaan pengguna, mulai dari tambah pengguna, edit, beserta hapus pengguna.

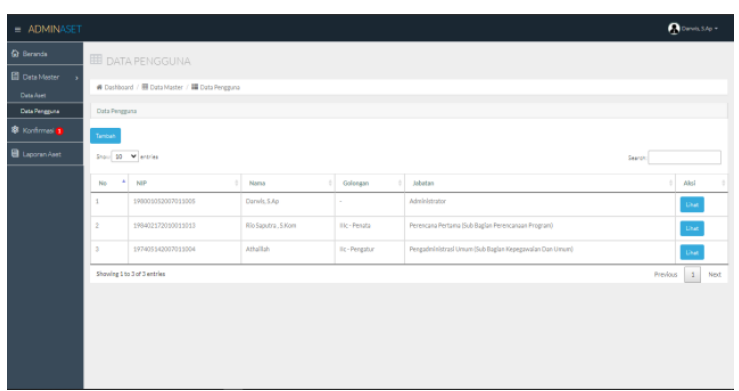

\section{Gambar 8 Tampilan Data Penggunna}

- Implementasi Tampilan Konfirmasi

Tampilan konfirmasi adalah tempat proses penentuan apakah barang bisa disetujui atau tidak.

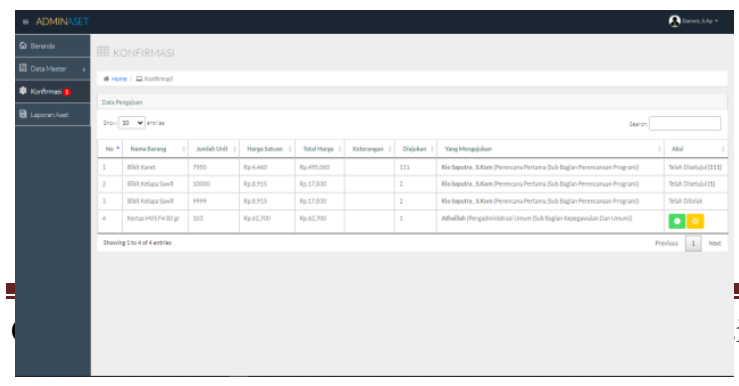

itas Dharma Andalas
- Implementasi Tampilan

Beranda/Halaman Utama(Pegawai)

Berikut ini adlah bentuk dari tampilan halaman beranda pada user pegawai.

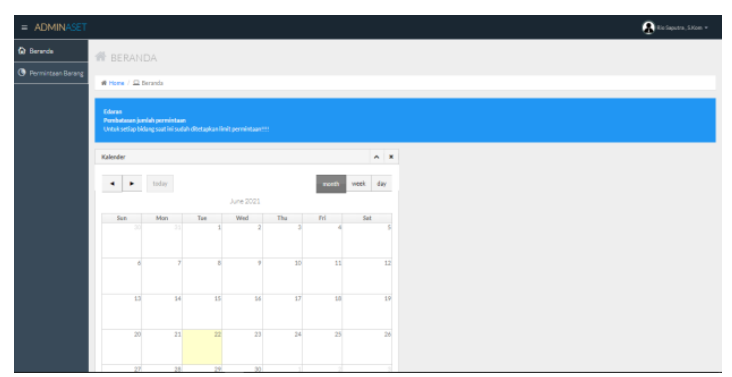

Gambar 20 Tampilan Beranda/Halaman Utama(Pegawai)

- Implementasi Tampilan Permintaan Barang(Pegawai)

Tampilan ini adalah proses untuk perlengkapan.

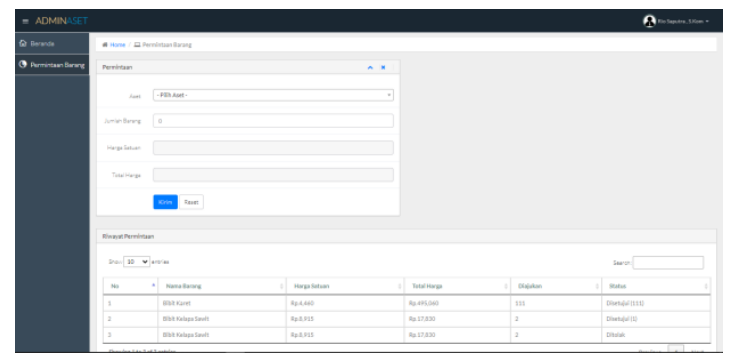

Gambar 11 Tampilan Permintaan Barang(Pegawai) melakukan permintaan barang ke admin

Gambar 9 Tampilan Konfirmasi 


\section{SIMPULAN}

Berdasarkan pembahasan yang telah dilakukan pada bab-bab sebelumnya dalam kerja praktik ini dapat disimpulkan.

1. Hasil dari analisa UAT (User Acceptence Test) yang diberikan kepada 6 responden yaitu dengan adanya sistem ini dapat memudahkan dalam pengelolaan aset yang dilakukan pada Dinas Perkebunan Provinsi Riau, terutama di bidang perlengkapan.

2. Kemudian hasil dari pengujian Black Box

3. Sistem Informasi Pendayagunaan Aset ini mencakup proses dalam pengelolaan aset seperti pengajuan aset, konfirmasi pengajuan, cetak laporan aset, dan pengelolaan data pengguna.

\section{UCAPAN TERIMAKASIH}

Terima kasih kepada pihak yang telah membantu dalam proses kerja praktek penulis, terutama dari pihak instansi sendiri Dinas Perkebunan Provinsi Riau, kemudian Dosen pembimbing saya Ibu Siti Ramadhani. Kemudian penulis juga berterimakasih kepada rekan-rekan seperjuangan yang telah mensupport dalam proses pembuatan jurnal dan sistem yang di bangun.

\section{DAFTAR PUSTAKA}

[1] S. Ramadhani, "A Review Comparative Mammography Image Analysis on Modified CNN Deep Learning Method," vol. 4, no. 1, pp. 54-61, 2021.

[2] M. R. Saputra, S. Ramadhani, and S. Baru, "Sistem informasi bantuan dana hibah operasional rumah ibadah kabupaten bengkalis," J. Teknol. dan Inf. Bisnis, vol. 3, no. 1, p. 148, 2021.

[3] D. Azzahra and S. Ramadhani,
"Pengembangan Aplikasi Online

Public Access Catalog (Opac) Perpustakaan Berbasis Web Pada Stai Auliaurrasyiddin Tembilahan," J. Teknol. Dan Sist. Inf. Bisnis, vol. 2, no. 2, pp. 152-160, 2020, doi: 10.47233/jteksis.v2i2.127.

[4] M. Ihsan and S. Ramadhani, "Sistem Informasi Pemetaan Pembangunan Kabupaten Indragiri Hilir," vol. 5, no. 1, 2021.

[5] F. Fawadhil and S. Ramadhani, "Rancang Bangun Sistem Informasi Pengaduan Layanan Teknis Bidang Teknologi Informasi dan Komunikasi," Semin. Nas. Teknol. Inf. Komun. dan Ind., no. 155, pp. 100-110, 2020.

[6] M. R. Asyari and S. Ramadhani, "Sistem informasi arsip surat menyurat," J. Teknol. dan Inf. Bisnis, vol. 3, no. 1, pp. 175-184, 2021.

[7] M. R. Saputra and S. Ramadhani, "Sistem Informasi Bantuan Dana Hibah Operasional Rumah Ibadah Kabupaten Bengkalis," J. Teknol. dan Inf. Bisnis, vol. 3, no. 1, pp. 147152, 2021.

[8] N. Ikhsan and S. Ramadhani, "Sistem Informasi Administrasi Surat Menyurat Kantor Wilayah Kementrian Agama Provinsi Riau," J. Teknol. Dan Inf. Bisnis, vol. 2, no. 2, pp. 141-151, 2020.

[9] R. Siti, "Sistem Pencegahan Plagiarisme Tugas Akhir Menggunakan Algoritma RabinKarp (Studi Kasus: Sekolah Tinggi Teknik Payakumbuh)," J. Teknol. Inf. Komun. Digit. Zo., vol. 6, no. 1, pp. 44-52, 2015.

[10] M. D. Ajie, "Pengertian Sistem Informasi Manajemen." 1996.

[11] N. Dengen and H. R. Hatta, 
"Perancangan Sistem Informasi Terpadu Pemerintah Daerah Kabupaten Paser," Inform. Mulawarman J. Ilm. Ilmu Komput., vol. 4, no. 1, pp. 47-54, 2009.

[12] B. Arismanto and S. Rahmadhani, "Pengembangan Sistem Penerimaan Mahasiswa Baru pada STIES Imam Asy Syafii Pekanbaru," J. IntraTech, vol. 3, no. 1, pp. 57-72, 2019.

[13] M. Ridwan, Muhammad and S. Ramadhani, "Rancangan Sistem Informasi Manajemen Aset di PT . Sentral Tukang Indonesia," $J$. CoreIT, vol. 3, no. 2, pp. 47-53, 2017.

[14] D. Azzahra and S. Ramadhani, "Pengembangan Aplikasi Online Public Access Catalog (OPAC)
Berbasis Web Pada STAI Auliaurrasyiddin Tembilanan," $J$. Teknol. Dan Sist. Inf. Bisnis, vol. 2, no. 2, pp. 152-160, 2020.

[15] R. A. Atmala and S. Ramadhani, "Rancang Bangun Sistem Informasi Surat Menyurat di Kementrian Agama Kabupaten Kampar," J. Intra Tech, vol. 11, no. 2, pp. 56-62, 2018.

[16] M. Tabrani and I. R. Aghniya, "Implementasi Metode Waterfall Pada Program Simpan Pinjam Koperasi Subur Jaya Mandiri Subang," J. Interkom J. Publ. Ilm. Bid. Teknol. Inf. dan Komun., vol. 14, no. 1, pp. 44-53, 2019. 